Molecules 2001, 6, 900-908

molecules

ISSN 1420-3049

http://www.mdpi.org

\title{
Efficient, Solvent-Free Oxidation of Organic Compounds with Potassium Dichromate in the Presence of Lewis Acids
}

\author{
Iraj Mohammadpoor-Baltork*, Majid M. Sadeghi and Abol-Hassan Adibi \\ Department of Chemistry, Isfahan University, Isfahan 81744, Iran, Fax: (+98) 3116689732. \\ * Author to whom correspondence should be addressed; e-mail: $\underline{\text { imbaltork@sci.ui.ac.ir }}$
}

Received: 9 August 2001; in revised form 25 September 2001 / Accepted: 22 October 2001 / Published: 31 October 2001

\begin{abstract}
The synthetic utility of potassium dichromate in the presence of Lewis acids under solid phase conditions is described. This reagent efficiently oxidizes alcohols, acyloins, oximes and semicarbazones to their corresponding carbonyl compounds, while trimethylsilyl and tetrahydropyranyl ethers, ethylene acetals and ketals undergo oxidative deprotection to produce carbonyl compounds efficiently.
\end{abstract}

Keywords: Oxidation, Organic compounds, Dichromate, Lewis acids, Solvent-free conditions.

\section{Introduction}

The total syntheses of complex molecules demand new methods in different areas of organic chemistry. Therefore, the development of reagents is always rewarding to synthetic organic chemistry. Oxidation is one of the most important classes of organic reactions from different points of view and effecting them under non-aqueous and aprotic conditions has found valuable applications in modern organic syntheses [1].

Potassium dichromate has been used extensively for the oxidation of different organic compounds under varied aqueous acidic conditions [1-6], but some of these methods suffer from disadvantages such as high reaction temperature, overoxidation of primary alcohols to carboxylic acids, long reaction times, low yields of the products and tedious workup. Its use as an oxidant under neutral conditions is also limited by its very low solubility in most organic solvents. 
Heterogeneous reactions facilitated by reagents supported on various solid inorganic surfaces have gained special attention in recent years [7-9]. The advantages of these methods over conventional homogeneous reactions are typically higher selectivity, enhanced reaction rates, milder reaction conditions, cleaner products and manipulative simplicity. As a continuation of our ongoing work on development of environmentally benign methods using solid supports [10], we now report a convenient method for the oxidation of different classes of organic compounds with potassium dichromate in the presence of Lewis acids under solid phase conditions.

\section{Results and Discussion}

Potassium dichromate is a readily available and inexpensive reagent. The catalytic effects of several Lewis acids upon the activity of this oxidant were thoroughly studied. For this purpose the oxidation of benzhydrol to benzophenone was investigated in the presence of $\mathrm{AlCl}_{3}, \mathrm{FeCl}_{3}, \mathrm{BiCl}_{3}, \mathrm{NiCl}_{2}, \mathrm{CeCl}_{3}$, $\mathrm{ZrCl}_{4}, \mathrm{SnCl}_{2} \cdot 2 \mathrm{H}_{2} \mathrm{O}, \mathrm{CuCl}_{2} \cdot 2 \mathrm{H}_{2} \mathrm{O}, \mathrm{MnCl}_{2} \cdot 4 \mathrm{H}_{2} \mathrm{O}$ and $\mathrm{CoCl}_{2} \cdot 6 \mathrm{H}_{2} \mathrm{O}$. The experimental results show $\mathrm{AlCl}_{3}$ to be the most effective catalyst for this purpose (Table 1).

Table 1. Percent Conversion of Benzhydrol to Benzophenone with $\mathrm{K}_{2} \mathrm{Cr}_{2} \mathrm{O}_{7}$ in the Presence of Different Lewis Acids Under Solid Phase Conditions

\begin{tabular}{|l|c|c|c|c|}
\cline { 2 - 5 } \multicolumn{1}{c|}{} & \multicolumn{4}{c|}{ Time (Min) } \\
\hline Lewis acid & $\mathbf{5}$ & $\mathbf{1 0}$ & $\mathbf{1 5}$ & $\mathbf{3 0}$ \\
\hline $\mathrm{AlCl}_{3}$ & 100 & - & - & - \\
$\mathrm{FeCl}_{3}$ & 65 & 75 & 77 & 80 \\
$\mathrm{BiCl}_{3}$ & 80 & 85 & 90 & 90 \\
$\mathrm{NiCl}_{2}$ & 30 & 50 & 60 & 60 \\
$\mathrm{CeCl}_{3}$ & 50 & 65 & 75 & 80 \\
$\mathrm{ZrCl}_{4}$ & 70 & 80 & 85 & 85 \\
$\mathrm{SnCl}_{2} \cdot 2 \mathrm{H}_{2} \mathrm{O}$ & 30 & 60 & 85 & 90 \\
$\mathrm{CuCl}_{2} \cdot 2 \mathrm{H}_{2} \mathrm{O}$ & 60 & 75 & 80 & 90 \\
$\mathrm{MnCl}_{2} \cdot 4 \mathrm{H}_{2} \mathrm{O}$ & 25 & 50 & 75 & 80 \\
$\mathrm{CoCl}_{2} \cdot 6 \mathrm{H}_{2} \mathrm{O}$ & 60 & 65 & 70 & 75 \\
\hline
\end{tabular}

Reagent ratio: $\mathrm{Ph}_{2} \mathrm{CHOH}: \mathrm{K}_{2} \mathrm{Cr}_{2} \mathrm{O}_{7}: \mathrm{AlCl}_{3}=1: 1: 1$

Primary and secondary benzylic alcohols are oxidized to their corresponding aldehydes and ketones with potassium dichromate in the presence of $\mathrm{AlCl}_{3}$ in high yield (Table 2). No overoxidation of primary alcohols to the corresponding carboxylic acids was observed under these conditions. 
Table 2. Oxidation of Alcohols to Carbonyl Compounds ${ }^{\mathrm{a}}$

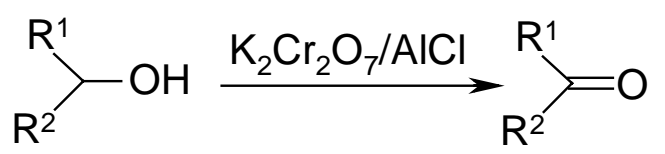

\begin{tabular}{|c|c|c|c|c|}
\hline Entry & $\mathbf{R}^{1}$ & $\mathbf{R}^{2}$ & Time (Min) & Yields $(\%)^{b}$ \\
\hline 1 & $\mathrm{C}_{6} \mathrm{H}_{5}$ & $\mathrm{H}$ & 5 & 95 \\
\hline 2 & 2- $\mathrm{MeOC}_{6} \mathrm{H}_{4}$ & $\mathrm{H}$ & 3 & 95 \\
\hline 3 & 3- $\mathrm{MeOC}_{6} \mathrm{H}_{4}$ & $\mathrm{H}$ & 4 & 90 \\
\hline 4 & $4-\mathrm{MeOC}_{6} \mathrm{H}_{4}$ & $\mathrm{H}$ & 3 & 98 \\
\hline 5 & 3,4-(MeO) $)_{2} \mathrm{C}_{6} \mathrm{H}_{3}$ & $\mathrm{H}$ & 2 & 95 \\
\hline 6 & $2-\mathrm{NO}_{2} \mathrm{C}_{6} \mathrm{H}_{4}$ & $\mathrm{H}$ & 30 & 72 \\
\hline 7 & $3-\mathrm{NO}_{2} \mathrm{C}_{6} \mathrm{H}_{4}$ & $\mathrm{H}$ & 30 & 74 \\
\hline 8 & $4-\mathrm{NO}_{2} \mathrm{C}_{6} \mathrm{H}_{4}$ & $\mathrm{H}$ & 25 & 75 \\
\hline 9 & $4-\mathrm{ClC}_{6} \mathrm{H}_{4}$ & $\mathrm{H}$ & 10 & 93 \\
\hline 10 & $4-\mathrm{BrC}_{6} \mathrm{H}_{4}$ & $\mathrm{H}$ & 15 & 87 \\
\hline 11 & 5-MeFuryl & $\mathrm{H}$ & 4 & 88 \\
\hline 12 & $\mathrm{C}_{6} \mathrm{H}_{5}$ & $\mathrm{CH}_{3}$ & 10 & 95 \\
\hline 13 & $4-\mathrm{ClC}_{6} \mathrm{H}_{4}$ & $\mathrm{CH}_{3}$ & 15 & 93 \\
\hline 14 & 4- $\mathrm{BrC}_{6} \mathrm{H}_{4}$ & $\mathrm{CH}_{3}$ & 15 & 90 \\
\hline 15 & 4- $\mathrm{PhC}_{6} \mathrm{H}_{4}$ & $\mathrm{CH}_{3}$ & 10 & 90 \\
\hline 16 & $3,4-(\mathrm{MeO})_{2} \mathrm{C}_{6} \mathrm{H}_{3}$ & $\mathrm{CH}_{3}$ & 3 & 98 \\
\hline 17 & $\mathrm{C}_{6} \mathrm{H}_{5}$ & $\mathrm{C}_{6} \mathrm{H}_{5}$ & 5 & $93^{c}$ \\
\hline 18 & 2-Pyridyl & $\mathrm{C}_{6} \mathrm{H}_{5}$ & 15 & 80 \\
\hline 19 & $\mathrm{C}_{6} \mathrm{H}_{5} \mathrm{CH}=\mathrm{CH}$ & $\mathrm{H}$ & 30 & $65^{\mathrm{d}}$ \\
\hline 20 & $\mathrm{C}_{6} \mathrm{H}_{5}$ & $\mathrm{C}_{6} \mathrm{H}_{5} \mathrm{CO}$ & 10 & 95 \\
\hline 21 & $4-\mathrm{CH}_{3} \mathrm{OC}_{6} \mathrm{H}_{4}$ & $4-\mathrm{CH}_{3} \mathrm{OC}_{6} \mathrm{H}_{4} \mathrm{CO}$ & 3 & 96 \\
\hline 22 & & & 10 & 90 \\
\hline 23 & & & 30 & 10 \\
\hline 24 & $\mathrm{CH}_{3}\left(\mathrm{CH}_{2}\right)_{6}$ & $\mathrm{H}$ & 30 & 10 \\
\hline
\end{tabular}

${ }^{a}$ All of the products are known compounds and were identified by comparison with authentic samples. ${ }^{\mathrm{b}}$ Isolated yields. ${ }^{\mathrm{c}}$ In the absence of $\mathrm{AlCl}_{3}$, benzhydrol was converted to benzophenone in only $10 \%$ yield after 30 min with $\mathrm{K}_{2} \mathrm{Cr}_{2} \mathrm{O}_{7}$. d $10 \%$ of benzaldehyde was obtained from the reaction mixture. 
$\alpha$-Hydroxy ketones are converted to $\alpha$-diketones in excellent yields without any carbon-carbon bond cleavage (entries 20,21). Saturated alcohols such as cyclohexanol and 1-heptanol are resistant towards oxidation with this reagent and the corresponding carbonyl compounds are obtained in poor yields (entries 23, 24). The oxidation of larger amounts $(5-10 \mathrm{mmol})$ of some alcohols was also investigated. The results were comparable to those of the small scale experiments, therefore, it seems that the methodology is also applicable for medium to large scale operations. In order to stress the selectivity of this method, an equimolar mixture of 4-methoxybenzyl alcohol and 1-heptanol was treated with an equimolar of potassium dichromate and aluminium chloride. The experimental results show that only 4-methoxybenzyl alcohol was oxidized selectively. It is noteworthy that many of the other chromium (VI) based oxidants either do not display such selectivity [11-19] or they require much longer reaction times $[20,21]$. Therefore, this selectivity represents a useful practical achievement in such oxidation reactions.

Potassium dichromate in the presence of aluminium chloride is also able to convert benzylic oximes and semicarbazones to their corresponding aldehydes and ketones in high yields (Table 3).

Table 3. Conversion of Oximes and Semicarbazones to Carbonyl Compounds ${ }^{\mathrm{a}}$

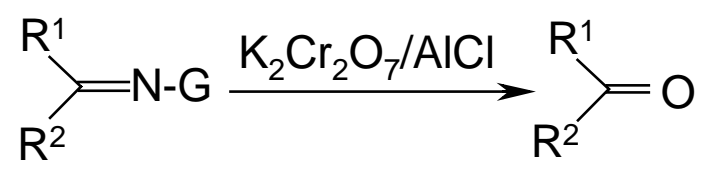

\begin{tabular}{|c|c|c|c|c|c|}
\hline Entry & $\mathbf{R}^{\mathbf{1}}$ & $\mathbf{R}^{\mathbf{2}}$ & $\mathbf{G}$ & Time(Min) & Yield(\%) $^{\mathbf{b}}$ \\
\hline 1 & $\mathrm{C}_{6} \mathrm{H}_{5}$ & $\mathrm{H}$ & $\mathrm{OH}$ & 10 & 92 \\
2 & $2-\mathrm{MeOC}_{6} \mathrm{H}_{4}$ & $\mathrm{H}$ & $\mathrm{OH}$ & 5 & 90 \\
3 & $4-\mathrm{MeOC}_{6} \mathrm{H}_{4}$ & $\mathrm{H}$ & $\mathrm{OH}$ & 5 & 95 \\
4 & $3,4-(\mathrm{MeO})_{2} \mathrm{C}_{6} \mathrm{H}_{3}$ & $\mathrm{H}$ & $\mathrm{OH}$ & 5 & 95 \\
5 & $3-\mathrm{NO}_{2} \mathrm{C}_{6} \mathrm{H}_{4}$ & $\mathrm{H}$ & $\mathrm{OH}$ & 30 & 75 \\
6 & $4-\mathrm{NO}_{2} \mathrm{C}_{6} \mathrm{H}_{4}$ & $\mathrm{H}$ & $\mathrm{OH}$ & 30 & 85 \\
7 & $5-\mathrm{MeFuryl}_{2}$ & $\mathrm{H}$ & $\mathrm{OH}$ & 10 & 85 \\
8 & $\mathrm{C}_{6} \mathrm{H}_{5}$ & $\mathrm{CH}_{3}$ & $\mathrm{OH}$ & 15 & 90 \\
9 & $4-\mathrm{BrC}_{6} \mathrm{H}_{4}$ & $\mathrm{CH}_{3}$ & $\mathrm{OH}$ & 15 & 95 \\
10 & $4-\mathrm{ClC}_{6} \mathrm{H}_{4}$ & $\mathrm{CH}_{3}$ & $\mathrm{OH}$ & 15 & 91 \\
11 & $4-\mathrm{BrC}_{6} \mathrm{H}_{4}$ & $\mathrm{CH}_{2} \mathrm{Br}$ & $\mathrm{OH}$ & 5 & 85 \\
12 & $4-\mathrm{PhC}_{6} \mathrm{H}_{4}$ & $\mathrm{CH}_{3}$ & $\mathrm{OH}$ & 15 & 86 \\
13 & $\mathrm{C}_{6} \mathrm{H}_{5}$ & $\mathrm{C}_{6} \mathrm{H}_{5}$ & $\mathrm{OH}$ & 15 & 85 \\
\hline
\end{tabular}




\begin{tabular}{|c|c|c|c|c|c|}
\hline 14 & & & $\mathrm{OH}$ & 10 & 77 \\
\hline 15 & & & $\mathrm{OH}$ & 30 & 10 \\
\hline 16 & $\mathrm{C}_{6} \mathrm{H}_{5}$ & $\mathrm{H}$ & $\mathrm{NHCONH}_{2}$ & 10 & 90 \\
\hline 17 & 4- $\mathrm{CH}_{3} \mathrm{OC}_{6} \mathrm{H}_{4}$ & $\mathrm{H}$ & $\mathrm{NHCONH}_{2}$ & 5 & 95 \\
\hline 18 & $4-\mathrm{NO}_{2} \mathrm{C}_{6} \mathrm{H}_{4}$ & $\mathrm{H}$ & $\mathrm{NHCONH}_{2}$ & 30 & 77 \\
\hline 19 & $4-\mathrm{ClC}_{6} \mathrm{H}_{4}$ & $\mathrm{H}$ & $\mathrm{NHCONH}_{2}$ & 10 & 87 \\
\hline 20 & $3,4-(\mathrm{MeO})_{2} \mathrm{C}_{6} \mathrm{H}_{3}$ & $\mathrm{H}$ & $\mathrm{NHCONH}_{2}$ & 5 & 95 \\
\hline 21 & 5-MeFuryl & $\mathrm{H}$ & $\mathrm{NHCONH}_{2}$ & 5 & 80 \\
\hline 22 & $\mathrm{C}_{6} \mathrm{H}_{5}$ & $\mathrm{CH}_{3}$ & $\mathrm{NHCONH}_{2}$ & 10 & 88 \\
\hline 23 & 4- $\mathrm{BrC}_{6} \mathrm{H}_{4}$ & $\mathrm{CH}_{3}$ & $\mathrm{NHCONH}_{2}$ & 10 & 85 \\
\hline 24 & $4-\mathrm{ClC}_{6} \mathrm{H}_{4}$ & $\mathrm{CH}_{3}$ & $\mathrm{NHCONH}_{2}$ & 15 & 85 \\
\hline 25 & 4- $\mathrm{BrC}_{6} \mathrm{H}_{4}$ & $\mathrm{CH}_{2} \mathrm{Br}$ & $\mathrm{NHCONH}_{2}$ & 10 & 92 \\
\hline 26 & 4- $\mathrm{PhC}_{6} \mathrm{H}_{4}$ & $\mathrm{CH}_{3}$ & $\mathrm{NHCONH}_{2}$ & 20 & 93 \\
\hline 27 & $\mathrm{C}_{6} \mathrm{H}_{5}$ & $\mathrm{C}_{6} \mathrm{H}_{5}$ & $\mathrm{NHCONH}_{2}$ & 10 & 90 \\
\hline 28 & & & $\mathrm{NHCONH}_{2}$ & 30 & 88 \\
\hline 29 & & & $\mathrm{NHCONH}_{2}$ & 30 & 5 \\
\hline
\end{tabular}

${ }^{a}$ All of the products are known compounds and were identified by comparison with authentic samples. ${ }^{\mathrm{b}}$ Isolated yields.

Further oxidation of aldehydes to their carboxylic acids was not observed. Under the same reaction conditions, saturated oximes and semicarbazones are converted to their corresponding carbonyl parent compounds in poor yields (Table 3, entries 15, 29).

In contrast to the method described in this paper, deoximation using pyridinium chlorochromate (PCC) suffers from long reaction times (12-94 h), low yields and low selectivity [22]. $\mathrm{PCC}-\mathrm{H}_{2} \mathrm{O}_{2}$ system is not sutiable for aldoximes and overoxidation products are usually produced and show low selectivity as well [23]. Therefore, this method is superior to PCC and $\mathrm{PCC}-\mathrm{H}_{2} \mathrm{O}_{2}$ system in terms of reaction times, yields and selectivity.

In order to further assess the capabilities of this reagent, we decided to also perform oxidative deprotection of trimethylsilyl and tetrahydropyranyl ethers, ethylene acetals and ketals. The treatment of a variety of TMS and THP ethers, ethylene acetals and ketals with potassium dichromate in the presence aluminium chloride under solid phase conditions afforded the corresponding carbonyl compounds in high yields (Tables 4 and 5). 
Table 4. Conversion of TMS and THP Ethers to Carbonyl Compounds ${ }^{\mathrm{a}}$

\begin{tabular}{|c|c|c|c|c|c|}
\hline Entry & $\mathbf{R}^{1}$ & $\mathbf{R}^{2}$ & $\mathbf{R}^{3}$ & Time(Min) & Yield $(\%)^{b}$ \\
\hline 1 & $\mathrm{C}_{6} \mathrm{H}_{5}$ & $\mathrm{H}$ & TMS & 15 & 90 \\
\hline 2 & $2-\mathrm{MeOC}_{6} \mathrm{H}_{4}$ & $\mathrm{H}$ & TMS & 15 & 95 \\
\hline 3 & $4-\mathrm{MeOC}_{6} \mathrm{H}_{4}$ & $\mathrm{H}$ & TMS & 10 & 95 \\
\hline 4 & $2-\mathrm{NO}_{2} \mathrm{C}_{6} \mathrm{H}_{4}$ & $\mathrm{H}$ & TMS & 30 & 80 \\
\hline 5 & $4-\mathrm{NO}_{2} \mathrm{C}_{6} \mathrm{H}_{4}$ & $\mathrm{H}$ & TMS & 30 & 81 \\
\hline 6 & $\mathrm{C}_{6} \mathrm{H}_{5} \mathrm{CH}=\mathrm{CH}$ & $\mathrm{H}$ & TMS & 30 & $65^{\mathrm{c}}$ \\
\hline 7 & $\mathrm{C}_{6} \mathrm{H}_{5}$ & $\mathrm{CH}_{3}$ & TMS & 20 & 82 \\
\hline 8 & 4- $\mathrm{ClC}_{6} \mathrm{H}_{4}$ & $\mathrm{CH}_{3}$ & TMS & 25 & 85 \\
\hline 9 & 4- $\mathrm{BrC}_{6} \mathrm{H}_{4}$ & $\mathrm{CH}_{3}$ & TMS & 25 & 90 \\
\hline 10 & 4- $\mathrm{PhC}_{6} \mathrm{H}_{4}$ & $\mathrm{CH}_{3}$ & TMS & 25 & 77 \\
\hline 11 & $3,4-(\mathrm{MeO})_{2} \mathrm{C}_{6} \mathrm{H}_{3}$ & $\mathrm{CH}_{3}$ & TMS & 10 & 96 \\
\hline 12 & $\mathrm{C}_{6} \mathrm{H}_{5}$ & $\mathrm{C}_{6} \mathrm{H}_{5}$ & TMS & 25 & 95 \\
\hline 13 & $4-\mathrm{ClC}_{6} \mathrm{H}_{4}$ & $\mathrm{C}_{6} \mathrm{H}_{5}$ & TMS & 20 & 90 \\
\hline 14 & \multirow{2}{*}{\multicolumn{2}{|c|}{$\underbrace{3}_{-\infty}$}} & TMS & 15 & 85 \\
\hline 15 & & & TMS & 30 & 5 \\
\hline 16 & $\mathrm{C}_{6} \mathrm{H}_{5}$ & $\mathrm{H}$ & THP & 5 & 95 \\
\hline 17 & $2-\mathrm{CH}_{3} \mathrm{OC}_{6} \mathrm{H}_{4}$ & $\mathrm{H}$ & THP & 5 & 95 \\
\hline 19 & 4- $\mathrm{CH}_{3} \mathrm{OC}_{6} \mathrm{H}_{4}$ & $\mathrm{H}$ & THP & 3 & 96 \\
\hline 20 & $3-\mathrm{NO}_{2} \mathrm{C}_{6} \mathrm{H}_{4}$ & $\mathrm{H}$ & THP & 30 & 75 \\
\hline 21 & $4-\mathrm{NO}_{2} \mathrm{C}_{6} \mathrm{H}_{4}$ & $\mathrm{H}$ & THP & 30 & 80 \\
\hline 22 & 4- $\mathrm{ClC}_{6} \mathrm{H}_{4}$ & $\mathrm{H}$ & THP & 10 & 90 \\
\hline 23 & $3,4-(\mathrm{MeO})_{2} \mathrm{C}_{6} \mathrm{H}_{3}$ & $\mathrm{H}$ & THP & 3 & 96 \\
\hline 24 & $\mathrm{C}_{6} \mathrm{H}_{5}$ & $\mathrm{CH}_{3}$ & THP & 10 & 87 \\
\hline 25 & $4-\mathrm{ClC}_{6} \mathrm{H}_{4}$ & $\mathrm{CH}_{3}$ & THP & 10 & 80 \\
\hline 26 & 4- $\mathrm{PhC}_{6} \mathrm{H}_{4}$ & $\mathrm{CH}_{3}$ & THP & 15 & 90 \\
\hline 27 & $\mathrm{C}_{6} \mathrm{H}_{5}$ & $\mathrm{C}_{6} \mathrm{H}_{5}$ & THP & 5 & 87 \\
\hline 28 & $4-\mathrm{ClC}_{6} \mathrm{H}_{4}$ & $\mathrm{C}_{6} \mathrm{H}_{5}$ & THP & 15 & 90 \\
\hline 29 & & & THP & 30 & 5 \\
\hline
\end{tabular}

${ }^{a}$ All of the products are known compounds and identified by comparison with authentic samples. ${ }^{\mathrm{b}}$ Isolated yields. ${ }^{\mathrm{c}} 15 \%$ of benzaldehyde was obtained from the reaction mixture. 
Table 5. Conversion of Ethylene Acetals and Ketals to Carbonyl Compounds ${ }^{\mathrm{a}}$

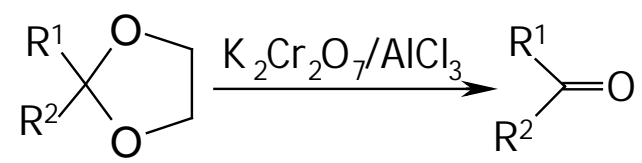

\begin{tabular}{|c|c|c|c|c|}
\hline Entry & $\mathbf{R}^{1}$ & $\mathbf{R}^{2}$ & Time(Min) & Yields $(\%)^{b}$ \\
\hline 1 & $\mathrm{C}_{6} \mathrm{H}_{5}$ & $\mathrm{H}$ & 5 & $92^{\mathrm{c}}$ \\
\hline 2 & $3-\mathrm{MeOC}_{6} \mathrm{H}_{4}$ & $\mathrm{H}$ & 5 & 90 \\
\hline 3 & 4- $\mathrm{MeOC}_{6} \mathrm{H}_{4}$ & $\mathrm{H}$ & 3 & 95 \\
\hline 4 & 3,4-(MeO) ${ }_{2} \mathrm{C}_{6} \mathrm{H}_{3}$ & $\mathrm{H}$ & 2 & 98 \\
\hline 5 & $3-\mathrm{NO}_{2} \mathrm{C}_{6} \mathrm{H}_{4}$ & $\mathrm{H}$ & 30 & 75 \\
\hline 6 & $4-\mathrm{ClC}_{6} \mathrm{H}_{4}$ & $\mathrm{H}$ & 10 & 90 \\
\hline 7 & $\mathrm{C}_{6} \mathrm{H}_{5}$ & $\mathrm{CH}_{3}$ & 10 & 95 \\
\hline 8 & $4-\mathrm{ClC}_{6} \mathrm{H}_{4}$ & $\mathrm{CH}_{3}$ & 15 & 90 \\
\hline 9 & $4-\mathrm{BrC}_{6} \mathrm{H}_{4}$ & $\mathrm{CH}_{3}$ & 15 & 86 \\
\hline 10 & 4- $\mathrm{PhC}_{6} \mathrm{H}_{4}$ & $\mathrm{CH}_{3}$ & 20 & 90 \\
\hline 11 & 3,4-(MeO) ${ }_{2} \mathrm{C}_{6} \mathrm{H}_{3}$ & $\mathrm{CH}_{3}$ & 3 & 96 \\
\hline 12 & 4- $\mathrm{BrC}_{6} \mathrm{H}_{4}$ & $\mathrm{CH}_{2} \mathrm{Br}$ & 10 & 92 \\
\hline 13 & $\mathrm{C}_{6} \mathrm{H}_{5}$ & $\mathrm{C}_{6} \mathrm{H}_{5}$ & 20 & 88 \\
\hline 14 & & & 15 & 85 \\
\hline 15 & & & 30 & 15 \\
\hline
\end{tabular}

a All of the products are known compounds and identified by comparison with authentic samples. ${ }^{\mathrm{b}}$ Isolated yields. ${ }^{\mathrm{c}}$ 2-phenyl1,3-dioxolane remained intact after $30 \mathrm{~min}$ in the presence of $\mathrm{K}_{2} \mathrm{Cr}_{2} \mathrm{O}_{7}$ without $\mathrm{AlCl}_{3}$

\section{Conclusions}

We present new methodology for the oxidation of organic compounds under solid phase conditions. In addition, the commercial availability and low cost of the reagent, high yields of the products, mild reaction conditions, easy workup and short reaction times are noteworthy advantages of this method and make this reagent practical bench-top oxidant.

\section{Acknowledgements}

We are thankful to the Isfahan University Research Council for partial support of this work. 


\section{Experimental}

\section{General}

All of the starting materials used in this work are commercially available or were prepared according to published procedures [24-27]. All of the products are known compounds and were identified by comparison of their physical and spectral data with those of authentic samples. Reported yields refer to isolated pure products.

\section{General Procedure for the Oxidation of Organic Compounds}

A mixture of substrate $(1 \mathrm{mmol})$, potassium dichromate $(1-2 \mathrm{mmol})$ and aluminium chloride (1 mmol) in a mortar was ground with a pestle for the time specified in Tables 2-5. The progress of the reaction was monitored by TLC or GLC. The mixture was extracted with $\mathrm{CH}_{2} \mathrm{Cl}_{2}$. The solvent was evaporated and the resulting crude material was purified on a silica-gel plate or silica-gel column with appropriate eluent to afford the pure product (Tables 2-5). In oxidation of alcohols, 1 mmol $\mathrm{K}_{2} \mathrm{Cr}_{2} \mathrm{O}_{7}$ and in other cases, 2 mmol $\mathrm{K}_{2} \mathrm{Cr}_{2} \mathrm{O}_{7}$ was used

\section{References}

1. Hudlicky, M. "Oxidations in Organic Chemistry/Reductions in Organic Chemistry Volume 1: Oxidations in Organic Chemistry", $2^{\text {nd }}$ ed., ACS Monograph series No 186, ACS: Washington, DC, 1990.

2. Hurd, C.D.; Meinert, R.N. Org. Synth., Collective Volume 1943, 2, 541.

3. Hutchins, R.O.; Natale, N.R.; Cook, W.J. Tetrahedron Lett. 1977, 18, 4167.

4. Hurd, C.D.; Garrett, J.W.; Osborne, E.N. J. Am. Chem. Soc. 1933, 55, 1082.

5. Glenn, R.A.; Bailey, J.R. J. Am. Chem. Soc. 1941, 63, 639.

6. Rao, A.V.R.; Chavan, S.P.; Sivadasan, L. Tetrahedron 1986, 42, 5065.

7. Toda, F. Acc. Chem. Res. 1995, 28, 480.

8. Abramovitch, A.; Org. Prep. Proced. Int. 1991, 23, 685.

9. Migos, D.M.P.; Baghurst, D.R. Chem. Soc. Rev. 1991, $20,1$.

10. (a) Hajipour, A.R.; Mohammadpoor-Baltork, I.; Nikbaghat, K.; Imanzadeh, G. Synth. Commun. 1999, 29, 1697; (b) Hajipour, A.R.; Mallakpour, S.E.; Mohammadpoor-Baltork, I.; Khoee, S. Chem. Lett. 2000, 120; (c) Hajipour, A.R.; Mohammadpoor-Baltork, I. Phosphorus, Sulfur and Silicon 2000, 164, 145.

11. Corey, E. J.; Suggs, J. W. Tetrahedron Lett. 1975, 16, 2647.

12. Firouzabadi, H.; Tamami, B.; Goudarzian, N.; Hatam, M.; Mansour Lakouraj, M. Synth. Commun. 1991, 21, 2077.

13. Santaniello, E.; Milani, F.; Casati, R. Synthesis 1983, 749. 
14. Aizpurua, J.M.; Juaristi, M.; Lecea, B.; Palomo, C. Tetrahedron, 1985, 41, 2903,

15. Firouzabadi, H.; Sharifi, A. Synthesis 1992, 999.

16. Lee, J.G.; Lee, J.A.; Sohn, S.Y. Synth. Commun. 1996, 26, 543.

17. Mohammadpoor-Baltork, I.; Sadeghi, M.M.; Mahmoodi, N.; Kharamesh, B. Indian J. Chem. 1997, $36 B, 438$.

18. Zhao, M.; Li, J.; Song, Z.; Desmond, R.; Tschaen, D.M.; Grabowski, E.J.J.; Reider, P.J. Tetrahedron Lett. 1998, 39, 5323.

19. Rajkumar, G.A.; Arabindoo, B.; Murugesan, V. Synth. Commun. 1999, 29, 2105.

20. Martinez, Y.; Heras, M.A.; Vaquero, J.J.; Garcia-Navio, J.L.; Alvares-Builla, J. Tetrahedron Lett. 1995, 36, 8513.

21. Chandrasekhar, S.; Takhi, M.; Mohapatra, S. Synth. Commun. 1996, 26, 3947.

22. Maloney, J.R.; Lyle, R.E.; Saavedra, J.E.; Lyle, G.G. Synthesis 1978, 212.

23. Drabowicz, J. Synthesis 1980, 125.

24. "Vogel's Textbook of Practical Organic Chemistry", 4th ed., Longman: Harlow, U.K., 1978; pp. 1112-1114.

25. Firouzabadi, H.; Karimi, B. Synth. Commun. 1993, 23, 1633.

26. Maity, G.; Roy, S.C. Synth. Commun. 1993, 23, 1667.

27. Meskens, F.A.J. Synthesis 1981, 501.

Sample Availability: All products reported in this paper are available from the authors.

(C) 2001 by MDPI (http://www.mdpi.org). Reproduction is permitted for noncommercial purposes. 